\title{
Digital literacy of modern higher education teachers
}

\author{
Maksim Vaskov ${ }^{1 *}$, Artur Isakov ${ }^{1}$, Vyacheslav Bilovus ${ }^{2}$, Alexander Bulavkin ${ }^{3}$, and Natalya \\ Mikhaylenko ${ }^{3}$ \\ ${ }^{1}$ Southern Federal University, 344006, Rostov-on-Don, Russia \\ ${ }^{2}$ Institute of Service and Entrepreneurship (branch) Don State Technical University in Shakhty, \\ 346500, Shakhty, Russia \\ ${ }^{3}$ Moscow University of the Ministry of internal Affairs of Russia named after V.Ya. Kikotya, \\ 117437, Moscow, Russia
}

\begin{abstract}
The expansion of digital technologies in all spheres of human life determines the digital transformation of education. This is due to the fact that the digital transformation of education brings the educational system itself in line with the requirements of the technological revolution and allows students to obtain relevant digital competencies in order to be qualified personnel for the economic sector. In connection with the digitalization of education and the active use of information technologies in the educational process, the requirements to the faculty of higher education are also changing. This became especially noticeable over the past year, when universities worked in a remote format. Therefore, the authors of the article turn to the issue of digital literacy of modern higher education teachers. Based on the structurally functional theory of T. Parsons, the modernist concept of E. Giddens and the theory of determination of human behavior by A. Maslow, it is shown what competencies a modern higher education teacher has in the context of the digital transformation of education. Based on the analysis, it should be noted that digital competencies include competencies related to information literacy, skills for interaction in an electronic environment; the ability to generate digital content; ensuring the safety of the physical and psychological health of users; the ability to identify and eliminate technical problems when working with digital devices. Digital literacy of teachers is the mastery of a set of the listed competencies. In general, the digital literacy index of university teachers is quite high, but unlike young people, teachers trust technological innovations to a lesser extent, which reduces their willingness to actively work with the digital educational environment. In our opinion, modern teachers need to transform their attitude to digitalization with the help of high-quality training in working with a digital educational environment.
\end{abstract}

\section{Introduction}

\footnotetext{
* Corresponding author: vaskovmaxsim@mail.ru
} 
Currently, we are actively observing the expansion of digital technologies in human life. The introduction into life of each "fruit" of technological progress causes a person to plunge into a completely new world - the world of high technologies, which radically transforms all spheres of human life.

Based on the forecast of the socio-economic development of Russia until 2036, we can note that digitalization and technological modernization of the economy and the use of new technologies ensure higher labor productivity. An important role is played here by adjusting the education system: mainly - the digital transformation of higher education.

Thus, education does not stand aside from digital transformations, since it is impossible to build a digital environment without qualified personnel with high digital competencies. In addition, the digital transformation of education brings the educational system itself in line with the requirements of the technological (digital) revolution.

The spread of digital technologies expands opportunities for each person, provides unlimited access to various digital tools, materials and services. The digitalization of higher education is aimed at creating student interest in learning, and represents an expansion of opportunities for teachers and students for interactive work and control of educational material. The digital transformation of education not only expands the capabilities of teachers and students, but also requires the actors of the educational process to acquire new knowledge, skills, and abilities to work effectively with digital tools, materials and services. With the use of information and communication technologies, the traditional educational process is changing, as well as the role of the teacher in the new educational environment is being transformed. The activities of a modern higher school teacher are aimed at spreading new models of organizing educational work with students. In this regard, along with considering the effectiveness of digitalization of education [1] and the risks of this process [2] described in the works of modern researchers, it is important to study the readiness of teachers for digital transformations and their digital competencies to work in the new educational space.

As part of this research work, we turn specifically to the digital literacy of modern higher education teachers, which will help to look at the problem of digitalization from a different angle.

\section{Methodology}

The modernization of education is of concern to the minds of many contemporary researchers. The issues of reforming the educational structure are considered from different angles and affect different aspects of education [3; 4]. Researchers pay special attention to the Bologna education system [5]. Great interest is also aroused by the digitalization of education: the positive aspects of this process and the risks [6].

Among the aspects that concern scientists involved in the digital transformation of education are the following: the use of information and communication technologies in the educational process [7], the development of online courses and the introduction of distance learning into the education system [8; 9], the creation of a unified digital educational space [10]. Researchers also address the issue of studying the competencies of scientific and pedagogical workers related to digital literacy, which will make it possible to fully use digital technologies in the educational process [11].

In 2020, due to the fact that the world was faced with a new infection, which complicated the epidemiological situation in many countries of the world, many processes began to go into remote mode. The process of teaching students was no exception. Universities of the world were actively involved in remote work with students. It is worth noting, that many Russian universities did not actively use distance learning as part of the educational process until 2020. Most often, universities included elective online courses in the curriculum. But 
already at the beginning of March 2020, absolutely all Russian universities had to master distance work, transform the educational environment, and teachers had to adapt their disciplines to the online format using various distance technologies and methods. Analyzing the data of many empirical studies concerning the views of students and teachers of Russian universities towards distance learning, we see that both students and teachers note the lack of digital competencies for effective distance learning. Many universities promptly developed and began to implement teacher-training programs aimed at mastering modern technologies for working in a distance format, which, in turn, speaks of the relevance and importance of this issue for the entire education system.

In our opinion, it is very important to address the problem of digital literacy of modern higher education teachers; this will help to understand the readiness of teachers for the digitalization of education in general and to determine their role in the educational space using distance technologies.

In connection with our goal, we turn to education as one of the important social institutions (M. Weber). Considering education as a social institution, we see that education is a set of institutions and organizations that perform the function of enlightenment and upbringing. The structural-functional approach (T. Parsons) allows defining all the functions of this institution. Moreover, since education is a system, modernist changes (E. Giddens) lead to the transformation of the structure of the educational system and its functions, which is reflected in the role of teachers within the framework of this transforming structure, which can be traced using A. Maslow's theory of human behavior determination.

Thus, the analyzed scientific literature regarding the selected problem field of research and the urgent transition to distance work in the educational process of higher school shows that it is very important to turn to digital literacy of the teaching staff of higher education, which will help us assess the readiness of teachers to digitalization of education.

\section{Results}

In order to determine the essence of digital literacy of modern higher education teachers, we turned to the definition of digital culture, to ways of expressing the digital transformation of education, and defined what digital competencies are.

Digital culture is the understanding by the population of modern information transfer technologies, their functions, as well as their correct and effective use both in work and in everyday life $[12 ; 13]$.

The digital transformation of education is associated with the introduction of a digital educational environment using information and communication technologies in the educational process, with the formation of models for organizing distance learning based on online courses, the active development of digital teaching materials and tools, which can include communication of teachers and students with the help of digital platforms and digital assessment of students through special electronic resources [14; 15].

The digital revolution is now at its peak, so the introduction of new technologies in the educational process and the formation of new learning models requires special competencies from the teaching staff. Competencies are a range of issues in which a person is aware and within which he has practical knowledge and experience. The competence of a teacher is a set of characteristics of knowledge, abilities and skills that are internalized by the individual and manifested as the ability and readiness of the individual to design actions when solving various labor problems.

For the effective fulfillment of his work activity, a modern teacher must have a set of the following competencies: cognitive; socio-psychological; managerial; informational; communicative; digital; competence in health preservation [16; 17]. These competencies allow teachers to be successful in their professional activities. However, in the light of the 
active digital transformation of education, the digital competencies of teachers, their digital literacy, are of particular importance.

Digital competencies include competencies related to information literacy, that is, the ability of teachers to find and critically evaluate information in the digital environment, on various information resources; they also include skills for cooperation and interaction in an electronic environment: knowledge of the rules and norms of behavior in the process of digital communication; the ability to form digital content, the ability to protect personal data; ensuring the safety of the physical and psychological health of users; as well as competencies related to the ability to identify and eliminate technical problems when working with digital devices $[18 ; 19]$.

Digital competencies constitute the digital literacy of a higher education teacher. Digital literacy is a system of knowledge, skills and attitudes that are necessary for a modern person to live in a digital society, and for a teacher to work successfully in a digital educational space. As defined by the United Nations: "digital literacy is the ability to safely and appropriately manage, understand, integrate, share, evaluate, create and access information through digital devices and networked technologies to participate in economic and social life" [20].

Do higher education teachers have sufficient digital literacy to actively engage in distance learning? Are they ready for the digitalization of education and can they effectively use digital technologies in the educational process?

We tried to find answers to the questions posed in the secondary analysis of empirical research data. The results of a study conducted by the analytical center "NAFI" show that the practice of using digital technologies by university teachers is as follows: $1 / 3$ of respondents believe that about $40 \%$ of their colleagues either do not use digital technologies at all, or use them very rarely. However, it is also noted that about $85 \%$ of university teachers are active users of the Internet, $2 / 3$ of teachers are interested in new applications, and about $60 \%$ are actively using social networks.

Thus, we see that the majority of university teachers keep up with the times and demonstrate high rates of digital literacy (Fig. 1).

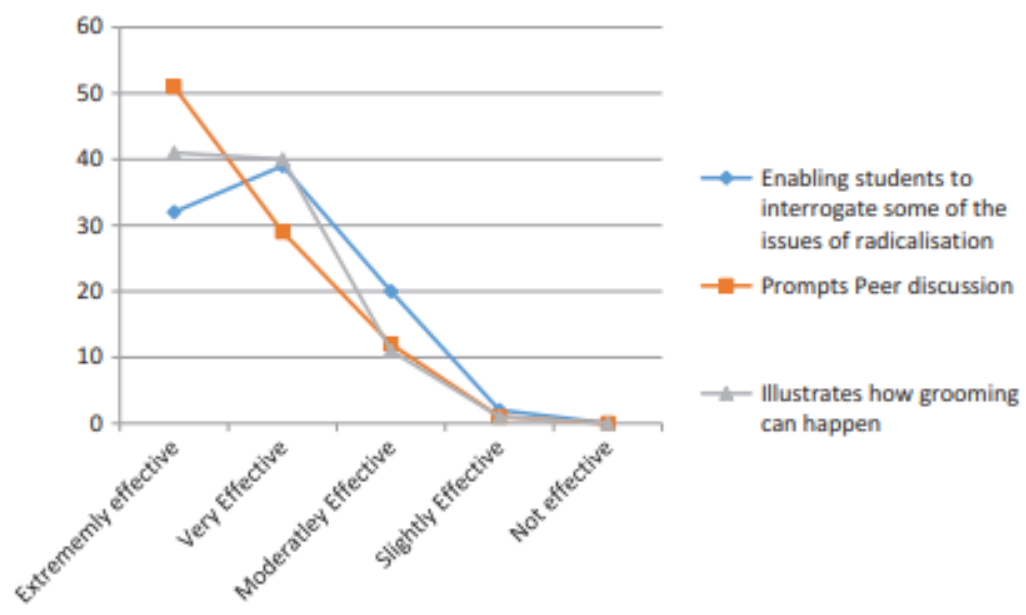

Fig. 1. Educators opinion on the effectiveness of simulations

When measuring digital literacy, the analytical center "NAFI" used such an indicator as the digital literacy index. The digital literacy index of university teachers is determined in accordance with the correlation of indicators such as information literacy, computer literacy, 
communication literacy, media literacy, attitude to innovation. According to NAFI estimates, the digital literacy index of university teachers is 88 points out of 100 , but it should be noted that, in comparison with young people, the indicator of attitude to technological innovation is reduced. Of course, here the younger generation gives a head start to teachers, since they treat various innovations with greater ease than teachers do. Teachers, in turn, strive to be more traditionalists, although due to their professional service, they are forced to work with new technologies, but sometimes they do not trust them.

Despite the fact that the level of digital literacy of modern higher education teachers is high, and they have enough knowledge, skills and follow the correct guidelines, their readiness to actively use information technologies in the process of educational activities and online learning is not so great, therefore, the digital competencies of higher education teachers require additional development. In our opinion, high-quality training in working with a digital educational environment will help increase the readiness of higher education teachers. We believe that as part of such training, it is necessary to familiarize teachers with the opportunities that the distance format presents for digital communication with students and the scientific community. Training should be aimed at developing teachers'skills to create electronic materials and exchange them with colleagues in the cloud. In addition, university staff must learn how to protect information, to use digital technologies creatively for solving various educational and extracurricular tasks.

Currently, in Russia, the state pays special attention to the development of the higher education sphere associated with the training of qualified personnel for priority sectors of the digital economy. Innopolis University has been chosen as a supporting educational center that will train personnel for the digital economy. In Innopolis, a program of additional professional education has now been developed and started to be implemented, where students, including higher education teachers will be taught the competencies that are in demand in the digital economy in the non-digital areas of the real sector of the economy. In practical classes, which held on a special platform, teachers will be able to analyze the higher educational programs. In addition, they will receive feedback from experts on the updated work programs of disciplines and the main professional educational program in order to introduce into these documents the necessary digital competencies a student must master during his training at the university.

\section{Conclusions}

Currently, the digital transformation of education is actively taking place, which is associated with the formation of a digital educational environment, where actors of the educational process use information and communication technologies. Digitalization of education is the formation of models for organizing distance learning through the development and implementation of online courses, the development of digital teaching materials and communication of teachers and students using digital platforms.

The quality of the educational process in higher education largely depends on the proficiency of information and communication technologies by university teachers.

The analysis of scientific literature and empirical data has shown that in order to fulfill their work activities effectively, successful teachers must have the following competencies: cognitive, socio-psychological, socio-organizational, information and computer, creative, (digital) communicative. In light of the active digital transformation of education, the digital competencies of teachers and their digital literacy are of particular importance.

The secondary analysis of empirical data shows that, in general, modern higher education teachers have a high digital literacy rate, but the willingness to use information and communication technologies in the educational process is not high, because modern teachers do not accept innovations very quickly. 
In our opinion, high-quality training in working with a digital educational environment will help increase the willingness of higher education teachers to work in a digital educational space. Currently, Innopolis has developed and started implementing a program of additional professional education, where students will be taught the competencies that are in demand in the digital economy in the non-digital areas of the real sector of the economy*.

* Research was financially supported by Southern Federal University, 2021 (Ministry of Science and Higher Education of the Russian Federation).

\section{References}

1. D. Orr, M. Weller, R. Farrow, Journal of interactive media in education. 1(5), (2019)

2. Marina A. Morozova, Elena V. Svinar, Necessity to research risks of education digitalization for successful training of future teachers, V international forum on teacher education. 447-454 (2019)

3. J. Santangelo, L. Hobbie, J. Lee, M. Pullin, E. Villa-Cuesta, A. Hyslop, International journal of stem education 8(1) (2021)

4. J.Y. Ma, Y.Z. Cai, Innovations in an institutionalized higher education system: the role of embedded agency (Higher education, 2021)

5. C. Dienel, Innovation-the European journal of social science research 32(4), 403-405 (2019)

6. O.V. Yureva, L.A. Burganova, O.Y. Kukushkina, G.P. Myagkov, D.V. Syradoev, Universal Journal of Educational Research 8(11B), 5965-5971 (2020)

7. V.A. Milićević, N.B. Denić, Z.C. Milićević, L.C. Arsić, M.A. Spasić-stojković, J.E. Petković, Stojanović, M.F. Krkic, N.S. Milovančević, A.G. Jovanović, Technological Forecasting and Social Change 166, (2021)

8. A.N. Sergeev, International Journal of Criminology and Sociology 10, 84-92 (2021)

9. N.M. Ndiaye, C.A. Diop, Massive Learning: Online Master class Course. Advances in Intelligent Systems and Computing 1192 AISC. 911-918 (2021)

10. O.Yu. Lyaginova, E.A. Smirnova, The concept of using electronic information space in the process of forming digital competencies of university students, CEUR Workshop Proceedings 2562, 168-173 (2021)

11. O. Zabolotska, N. Zhyliak, N. Hevchuk, N. Petrenko, O. Alieko, Journal of Optimization in Industrial Engineering 14(1), 43-50 (2021)

12. LV. Baeva, Innovation theory and expert study 2(9), 110-118 (2012)

13. N. Barbuti, DTUC '18, P 1 INT C DIG TOOLS 21, 1-3 (2018).

14. K. Cho, International Journal for Educational Media and Technology. (2017)

15. K. Ratheeswari, Journal of Applied and Advanced Research. 3(S1), 45 (2018)

16. E.A. Karapetyan, Revista Gênero e Direito 9(4), 830-845 (2020)

17. N.Kh. Gafiatulina, V.V. Kasyanov, P.S. Samygin, S.I. Samygin, Russian society in conditions of self-isolation. Social effects and consequences of the Covid-19 pandemic. (Moscow, 2020).

18. N.K. Gafiatulina, L.I. Makadey, I.V. Gluzman, A.D. Lozhechkina, L.A. Volkova, A.P. Bandurin, EurAsian Journal of BioSciences 13(2), 1557 - 1563 (2019)

19. S. Carretero, R. Vuorikari, Y. Punie, DigComp 2.1, The Digital Competence Framework for Citizens with eight proficiency levels and examples of us (Publications Office of the European Union, Luxembourg, 2017). 
20. A Global Framework of Reference on Digital Literacy Skills for Indicator" United Nations (Unesco Institute for statistics, 2018). 